\title{
PEREMPUAN SEBAGAI WALI NIKAH: LARANGAN ATAU PERINGATAN
}

\author{
Nurzulia Febri Hidayati \\ UIN Walisongo Semarang \\ E-mail: nuzuliafebri2002@gmail.com
}

\begin{abstract}
As is believed to be down and down in the marriage contract, the concept of guardians is an inseparable part, because this is one of the requirements of the legal Islamic marriage that must be met. However, the goal orientation required by marriage guardians to shift, because the context of the growing era. Formerly the marriage guardian was formulated to protect the rights of women for the realization of a harmonious marriage but later on its development precisely the dominant marriage guardians, thus neglecting the rights, choices and interests of the bride. Stereotypes of women as weak creatures result in him always in control of a marriage guardians (father, grandfather or family). Because justification of women can not be married by itself, it is deemed not to be able to marry someone else, including marrying her daughter even if she is someone who has emotional closeness. Though one step ahead of women is not far behind with men in terms of acting skills, if it is used as female reasoning does not deserve to be a guardian then it seems not right. Indeed, the construction of such guardians needs to be reexamined whether it is an absolute prohibition or impact of a perpetual tradition.
\end{abstract}

Keywords: Construction of female guardians, the prohibition of women becoming marriage guardians.

\begin{abstract}
Abstrak
Sebagaimana diyakini turun-menurun dalam akad nikah, konsep wali merupakan bagian yang tidak terpisahkan, sebab hal ini merupakan salah satu syarat dari legal pernikahan Islam yang harus dipenuhi. Akan tetapi Orientasi tujuan disyaratkannya wali nikah mengalami pergeseran, karena melihat konteks zaman yang semakin berkembang. Dahulu wali nikah diformulasi untuk melindungi hak-hak perempuan demi terwujudnya pernikahan harmonis tetapi kemudian pada perkembangannya justru wali nikah yang seringkali dominan, sehingga mengabaikan hak-hak, pilihan-pilihan dan kepentingan calon mempelai perempuan. Stereotip perempuan sebagai makhluk yang lemah mengakibatkan dirinya senantiasa dalam kendali seorang wali (ayah, kakek atau keluarga). Karena justifikasi perempuan tidak dapat menikah dengan sendirinya, maka dipandang tidak akan mampu menikahkan orang lain, termasuk menikahkan anak perempuannya sekalipun dia adalah orang yang memiliki kedekatan secara emosional. Padahal selangkah lebih maju perempuan tidak jauh tertinggal dengan laki-laki dalam hal kecakapan bertindak, jika hal itu dijadikan reasoning perempuan tidak pantas menjadi wali maka sepertinya tidaklah tepat. Sesungguhnya konstruksi wali yang demikian perlu dire-thinking apakah merupakan larangan mutlak atau impact dari tradisi yang dilanggengkan.
\end{abstract}

Kata Kunci: Konstruksi wali perempuan, Larangan perempuan menjadi wali nikah 


\section{PENDAHULUAN}

Dalam hukum perkawinan di Indonesia, wali merupakan komponen yang harus ada dalam akad nikah, sebagai pihak yang mewakili calon mempelai perempuan. Wali nikah tersebut disyaratkan antara lain harus lakilaki. Namun seiring dengan adanya ide-ide persamaan dan kesetaraan antara laki-laki dan perempuan di tengah masyarakat, muncul pertanyaanpertanyaan seperti: masih perlukah adanya wali nikah bagi perempuan dewasa ? Bukankah perempuan dewasa, sebagaimana laki-laki, sudah dapat menentukan pilihan dan kehendaknya sendiri ? Kalaupun masih perlu ada wali, maka perlukah dibatasi bagi siapa saja wali itu diperlukan ? Kemudian apakah wali nikah itu harus laki-laki, apakah perempuan tidak bisa menjadi wali nikah?

Pertanyaan-pertanyaan tersebut muncul antara lain karena dalam realitanya wali nikah justru yang dominan dalam akad nikah, sementara calon mempelai perempuan sendiri seringkali kurang dilibatkan dalam menentukan pilihan dan keputusan bagi pernikahannya. Sebaliknya, dalam masyarakat sekarang perempuan dapat mensejajarkan dirinya dengan lakilaki di ruang-ruang publik, sehingga ide adanya kesetaraan, seperti tidak perlu ada wali nikah bagi perempuan dewasa dan perempuan juga bisa bertindak sebagai wali, kemudian muncul di tengah masyarakat.

Dengan kata lain, di satu sisi ada perubahan orientasi tujuan adanya wali nikah, yaitu dulunya wali nikah diformulasi untuk melindungi hak-hak perempuan demi terwujudnya pernikahan harmonis tetapi kemudian pada perkembangannya justru wali nikah yang seringkali dominan, sehingga mengabaikan hak-hak, pilihan-pilihan dan kepentingan calon mempelai perempuan. Kemudian di sisi lain mayarakat telah berubah, termasuk dalam memandang relasi antara laki-laki dan perempuan. Karena itu kemudian muncul isu-isu bagaimana jika perempuan yang menjadi wali nikah terlepas dari apakah masih ada wali laki-laki dari garis ayah ke atas atau perempuan pada posisi dia adalah satu-satunya wali yang masih ada.

\section{Konstruksi Wali Nikah dalam Fiqh Konvensional}

Kata wali dalam kamus besar bahasa Indonesia diartikan sebagai pengasuh atau pembimbing atau orang tua. ${ }^{1}$ Perwalian dari bahasa Arab adalah walayah atau wilayah ${ }^{2}$ yaitu hak yang diberikan oleh syariat kepada

${ }^{1}$ Porwadarminta, KBBI, (Jakarta: Balai Pustaka, 1995), h. 92

${ }^{2}$ Muhammad Bagir al-Hasby, Fiqh Praktis, (Bandung: Mizan, 2002), h. 56 
wali untuk melakukan sesuatu, bahkan dengan paksaan (mujbir). ${ }^{3}$ Jadi, perwalian merupakan kewenangan yang diberikan kepada seseorang umtuk melakukan sesuatu perbuatan hukum sebagai wakil untuk kepentingan dan atas nama anak yang tidak mempunyai kedua orang tua, atau untuk anak yang mempunyai kedua orang tua atau orang tuanya masih hidup tetapi tidak cakap melakukan perbuatan hukum. ${ }^{4}$ Dalam suatu pernikahan, konsep wali itu merupakan bagian yang tak terpisahkan sebab hal ini merupakan salah satu syarat dari legal pernikahan Islam yang harus dipenuhi.

Wali (biasanya laki-laki) yang memiliki hak untuk menikahkan kerabat perempuannya, sesungguhnya telah ada semenjak masa pra-Islam. Pada saat itu wali memilki hak prerogatif dalam memilih dan menentukan pernikahan kerabat perempuannya dengan siapa saja yang mereka kehendaki, tanpa meminta pesetujuan dan izin terlebih dahulu. Empat wali yang dapat menikahkan kerbat perempuannya ialah:

1) Wali Nasab

Yaitu wali nikah karena ada hubungan darah nasab dengan perempuan yang akan melangsungkan pernikahan. ${ }^{5}$ Adapun urutannya sebagai berikut:
a. Ayah kandung
b. Kakek
c. Saudara laki-laki seayah dan seibu (saudara kandung)
d. Saudara laki-laki seayah
e. Anak laki-laki
f. Anak laki-laki dari saudara laki-laki kandung
g. Anak laki-laki dari saudara ayah
h. Saudara laki-laki ayah (paman)

3 Suatu kekuasaan seorang wali (bapak atau kakek) untuk memaksa menikahkan seorang anak atau cucu perempuannya tanpa persetujuan yang bersangkutan. Dengan konnsep ini ada kemungkinan terjadi perkawinan tanpa persetujuan dari calon mempelai, dengan syarat walinya adalah bapak atau kakek. Dalam hukum fiqh, terutama di kalangan empat madzhab masih mengakui adanya hak ijbar. Adanya hak ijbar ini, maka kebebasan seorang anak atau cucu perempuan menjadi terbatas dan terdapat ketidakseimbangan hak diantara keduanya. Menurut UU No 1 Tahun 1974 wali merupakan syarat perkawinan tetapi kaitanyya dengan hak ijbar, UU ini lebih berdasarkan atas persetujuan kedua belah pihak. Hal ini tercantum dalam UU No 1 Tahun 1974 Pasal 6 ayat 1. Lihat, Khoiruddin Nasution, Hukum Perkawinan I, (Yogyakarta: AKAdeMIA + TAZZAFA, 2013 ), lihat Kamala Muchtar, Asas-Asas Hukum Islam Tentang Perkawinan, Cet ke-3, (Jakarta: Bulan Bintang, 1993), h. 101

4 Pasal 1 Ketentuan Umum huruf h Kompilasi Hukum Islam, lihat Undang-Undang R. I. Nomor 1 Tahun 1974 tentang Perkawinan dan Kompilasi Hukum Islam, (Bandung: Citra Umbara, 2017), h. 368

5 Wahbah al-Zuhaili, Usul al-Fiqh al-Islami, Juz I, (Damaskus:Dar al-Fikr, 1986), h. 163. Lihat Slamet Abidin dan Aminuddin, Fiqh Munakahat, Juz I (Bandung: Pustakan Setia, 1999 , h. 89 


\section{8 | Nurzulia Febri Hidayati}

i. Anak laki-laki dari saudara laki-laki ayah (sepupu). ${ }^{6}$

2) Wali Maula

Ialah perwalian yang digunakan dalam pernikahan budak yang

telah dimerdekakan, artinya wali yang menikahkan budaknya sendiri.

3) Wali Tahkim

Ialah wali yang diangkat calon mempelai suami atau calon isteri.

4) Wali Hakim

Ialah penguasa atau orang yang ditunjuk oleh penguasa

(pemerintah) untuk menikahkan seorang perempuan.

Mengenai sejauhmana peran aktif perempuan dalam akad nikah, sebenarnya terdapat perbedaan pendapat di kalangan ulama. Perbedaan pendapat tersebut secara garis besar berkaitan dengan dua hal, yaitu pertama, apakah perempuan dapat menikahkan dirinya sendiri ataukah harus dengan perantara wali dan kedua, apakah perempuan dapat menjadi wali nikah atau tidak bisa. Perempuan yang dimaksud disini adalah perempuan dewasa, karena untuk anak yang belum dewasa baik laki-laki maupun perempuan, para ulama sepakat bahwa mereka harus melalui perantara wali apabila akan melakukan akad nikah. ${ }^{7}$

Jumhur ulama berpendapat bahwa perempuan berbeda dengan lakilaki, tidak dapat menikahkan dirinya sendiri. Sehingga adanya wali perempuan merupakan suatu keniscayaan bagi syarat sahnya akad nikah. Sementara menurut Imam Malik keharusan adanya wali tersebut hanya bagi perempuan yang memilki status sosial yang tinggi (syarifah), sedangkan perempuan biasa dapat menikahkan dirinya sendiri atau meminta kepada seorang laki-laki dewasa (walaupun bukan kerabatnya) untuk menikahkan dirinya.

Berbeda dengan masyoritas ulama, Abu Hanifah dan ulama Hanafiyyah secara umum berpendapat bahwa perempuan dewasa dapat menikahkan dirinya sendiri tanpa campur tangan wali. Sehingga bagi mereka adanya wali dalam akad nikah tidak disyaratkan sama sekali. Sementara dari Dawud alDzahiri membedakan antara gadis dan janda. Apabila janda maka dapat menikahkan dirinya sendiri sedangkan bila gadis harus dengan wali. Menurut

${ }^{6}$ Lihat Imam Nawawi al-Majmu', Syarh al-Muhazddab, Juz 17, h. 312. Lihat, Taqiyuddin Abu Bakar bin Muhammad al-Husaini, Kifayat al-Akhyar fi Hilli Ghayah al-Ikhtisar, (Damaskus: Dar al-Khair, 1994), maktabah Syamilah

${ }^{7}$ Al-Sayyid Sabiq, Fiqh Sunnah, Juz II, (Semarang: Maktabah wa Matba'at Toha Putera, t.t), h. 116 
Abu Tsaur sesungguhnya yang dipersyaratkan itu bukan adanya wali yang menikahkan tetapi izin dari wali. ${ }^{8}$

Perbedaan ulama tersebut disebabkan tidak adanya teks yang jelas dan pasti dalam al-Quran maupun Sunnah yang menunjukkan keharusan adanya wali. Semua dalil yang digunakan mereka sama-sama masih interpretable. ${ }^{9}$ Berikut klasifikasi ulama madzhab dalam hal ini wali:

\begin{tabular}{|l|l|}
\hline \multicolumn{1}{|c|}{ Imam Madzhab } & \multicolumn{1}{c|}{ Hukum wali } \\
\hline Hanafi, as-Sya'bi, az-Zuhri & Sunnah \\
\hline $\begin{array}{l}\text { Imam Syafi'i, Imam Maliki } \\
\text { dan Imam Hanbali }\end{array}$ & Wajib \\
\hline \multicolumn{1}{|c|}{ Imam } & \multicolumn{1}{c|}{ Wali Perempuan } \\
\hline Jumhur Ulama & Tidak boleh \\
\hline Imam Hanafi & Boleh \\
\hline
\end{tabular}

Sebagaimana perbedaan pendapat dalam hal apakah harus ada wali atau tidak, para ulama juga berpendapat apakah perempuan dapat menjadi wali atau tidak. Sebagaimana tidak dapat menikahkan dirinya sendiri, menurut mayoritas ulama, perempuan juga tidak dapat menikahkan orang lain. Baik dengan cara dia menjadi wali atau menjadi wakil dari orang lain. ${ }^{10}$ Sementara Abu Hanifah berpendapat bahwa disamping dapat menikahkan dirinya sendiri, perempuan juga dapat menjadi wali bagi anaknya yang belum

8 Muhammad Ibn Isma'il al-San'ani, Subul al-Salam Syarh Bulugh al-Maram min Adillat al-Ahkam, Juz II, (Ttp: Dar al-Fikr, t.t), h. 11

9 Ayat-ayat al-Quran yang dijadikan dasar bagi ulama yang mensyaratkan adanya wali antara lain adalah QS an-Nur (24): 32 dan QS. Al-Baqarah (2): 221. Sementara, haditsnya yang paling masyhur adalah riwayat A'isyah yang menyatakan bahwa setiap perempuan yang menikah tanpa seizin walinya maka nikahnya batal, dan apabila walinya tidak bersedia menikahkan maka walinya adalah sultan atau pemerintah. Sementara ulama yang tidak mensyaratkan adanya wali antara lain berargumen dengan QS al-Baqarah (2): 230, 232, 234 dan 340. Hadits-hadits tentang adanya wali nikah dipahami oleh kelompok ini hanya ditujukan bagi orang-orang yang kurang cakap bertindak hukum seperti orang yang belum dewasa dan orang yang kurang akalnya. Untuk melihat dalil dan argumen dari masing-masing pendapat para ulama diatas, lihat misalnya: Muhammad Ibn Isma'il alSan'ani, Subul al-Salam Syarh Bulugh al-Maram min Adillat al-Ahkam, h. 117-118. Ibnu Rusyd, Bidayat al-Mujtahid wa Nihayat al-Maqashid, Juz II, (Ttp: Syirkat al-Nur Asia, t.t), h. 78. Dan al-Sayyid Sabiq, Fiqh al-Sunnah, Juz II, h. 114

10 Mereka antara lain berargumen dengan Hadits riwayat Ibnu Majah dan adلا تزوج المراة المراة و لا Daruquthni dari Abu Hurairah yang menyatakan bahwa Nabi bersabda: تزوج المراة نفسها. Artinya: seorang perempuan tidak dapat menikahkan perempuan (lain) dan juga tidak dapat menikahkan dirinya sendiri. 


\section{0 | Nurzulia Febri Hidayati}

dewasa atau menjadi wakil dari orang lain untuk menikahkan. ${ }^{11}$ Pernikahan yang sah sesungguhnya bukan didasarkan pada kewenangan wali, tetapi didasarkan pada persetujuan dari mempelai perempuan. ${ }^{12}$

\section{Konstruksi Wali Nikah dalm Perundang-Undangan Indonesia}

Didalam Undang-Undang No 1 tahun 1974 pasal 6 ayat 213, ayat $13^{14}$ dan ayat $4^{15} \mathrm{UU}$ perkawinan menganggap bahwa wali adalah izin dari orang tua, itupun bila calon mempelai laki-laki maupun perempuan yang belum dewasa (di bawah 21 tahun), bila dewasa (dua puluh satu tahun ke atas) tidak perlu izin dari orang tua. ${ }^{16}$ Pada prinsipnya dalam hal perwalian yang paling urgen ialah kehadiran wali itu sendiri. Dalam perundang-undangan perkawinan Indonesia, wali nikah menjadi salah satu rukun nikah, tanpa wali perkawinan tidak sah. ${ }^{17}$ Sejalan dengan keharusan adanya wali maka prinsipnya wali nikah dalan perundang-undangan perkawinan Indonesia

11 Al-San'ani, Subul al-Salam, Juz III, h. 120. Walaupun perempuan dapat menjadi wali nikah, namun urutannya setelah kerabat laki-laki ('asabah). Apabila tidak ada 'asabah baru mereka dapat menjadi wali. Lihat al-Zuhaili, al Fiqh Islami, Juz VII, h. 196 dan 200

12 Abu Hanifah mendasarkan pandangannya pada riwayat bahwa seorang perempuan telah menikahkan anak perempuannya dengan persetujuannya. Setelah para wali laki-lakinya mengetahui, mereka menolak pernikahan itu. Kemudian masalah itu dibawa kepada Ali bin Abi Thalib dan ia membolehkan dan menganggap sah pernikahan itu. Lihat Syamsuddin al-Sharakhsi, al-Mabsut, Juz V, (Beirut: Dar al-Ma'rifah, 1989), h. 10

13 Untuk melangsungkan perkawinan seseorang belum mencapai umur 21 tahun harus mendapat izin orang tua.

14 Dalam hal seseorang dari orang tua meninggal dunia atau dalam keadaan tidak mampu menyatakan kehendaknya, maka izin yang dimaksud ayat 2 pasal ini cukup diperoleh dari orang tua yang masih hidupatau dari orang tua yang mampu menyatakan kehendaknya.

15 Dalam hal orang tua telah meninggal dunia atau dalam keadaan tidak mampu untuk menyatakan kehendaknyamaka izin diperoleh dari wali orang yang memelihara atau keluarga yang mempunyai hubungan darah dalam garis keturunan lurus ke atas selama mereka masih hidup dan dalam keadaan menyatakan kehendaknya.

16 Moh. Idris Ramulyo, Tinjauan Beberapa Pasal Undang-Undang no 1 tahun 1974 dari Segi Hukum Perkawinan Islam, (Jakarta: Ind-Hillco, 1985), h. 184-185

17 KHI pasal 14, "untuk melaksanakan perkawinan harus ada calon suami, calon isteri, wali nikah, dua orang saksi, ijab dan qabul. Kemudian disebutkan lebih tegas pada KHI pasal 19: wali nikah dalam perkawinan merupakan merupakan rukun yang harus dipenuhi bagi calon mempelai wanita yang bertindak untuk menikahinya ". 
adalah wali nasab. Namun dalam kondisi tertentu posisi wali nikah dapat digantikan wali hakim. ${ }^{18}$

Bersamaan dengan ini ada konsep fikih yang menyebutkan adanya wali mujbir yakni hak bapak atau kakek memaksa menikahkan seorang wanita tanpa persetujuannya. Pada prakteknya hal ini sudah tidak berlaku lagi karena perkawinan menurut UU No 1 tahun 1974 pasal 6 ayat 1 disebutkan bahwa perkawinan harus didasarkan atas persetujuan kedua calon mempelai. Sedang proses untuk mengetahui ada tidaknya persetujuan dari calon mempelai dilakukan dengan menanyakan kuduanya sebelum akad dihadapan dua orang saksi.

Apabila kita kontekskan dalam hukum positif Islam di Indonesia yang terdapat dalam UU No. 1 Tahun 1974 tentang Perkawinan dan PP No. 9 Tahun 1975 tentang pelaksanaan UU tersebut, masalah wali nikah ternyata belum didefinisikan secara eksplisit sebagai syarat dan rukun nikah. Dalam kedua peraturan ini yang disinggung adalah batas minimal usia nikah. Sedangkan pandangan wali di dunia Islam dapat dibuat sebagaimana berikut: 19

\begin{tabular}{|l|l|l|}
\hline No & \multicolumn{1}{|c|}{ Negara } & \multicolumn{1}{|c|}{ Ketentuan } \\
\hline 1 & Tunisia & $\begin{array}{l}\text { Wali tidak menjadi syarat atau } \\
\text { rukun nikah }\end{array}$ \\
\hline 2 & Ciprus & $\begin{array}{l}\text { Perlu izin wali tapi tidak menjadi } \\
\text { syarat atau rukun nikah }\end{array}$ \\
\hline 3 & Yordania & $\begin{array}{l}\text { Membedakan gadis dengan janda, } \\
\text { janda tidak perlu izin wali }\end{array}$ \\
\hline 4 & Syiria \& Somalia & $\begin{array}{l}\text { Membedakan gadis dewasa \& } \\
\text { belum dewasa, belum dewasa } \\
\text { tidak perlu izin wali }\end{array}$ \\
\hline 5 & Lebanon & $\begin{array}{l}\text { Wali harus ada tapi begitu longgar } \\
\text { untuk diganti wali hakim }\end{array}$ \\
\hline 6 & $\begin{array}{l}\text { Indonesia, Malaysia, Brunei, } \\
\text { Philipines, Maroko, Aljazair, Libya, } \\
\text { Sudan dan Yaman }\end{array}$ & Wali menjadi rukun nikah \\
\hline 7 & $\begin{array}{l}\text { Brunei, Philipines, Druze Lebanon, } \\
\text { Maroko, Aljazair, libya, Ciprus dan } \\
\text { Sudan }\end{array}$ & Harus ada persetujuan mempelai \\
\hline
\end{tabular}

18 Yakni: kalau tidak ada wali nasab; tidak mungkin menghadirkan wali nasab; tidak diketahui tempat tinggal wali nasab; wali nasab ghaib; wali nasab engan menikahkan. Lihat KHI pasal 23 ayat 1

${ }^{19}$ Khoiruddin Nasution, Hukum Perkawinan I, h. 125 


\begin{tabular}{|l|l|l|}
\hline 8 & Maroko & Masih mengakui hak ijbar \\
\hline 9 & Irak dan Malaysia & Dihukum bagi pemaksa nikah \\
\hline
\end{tabular}

\section{PEREMPUAN SEBAGAI WALI NIKAH: LARANGAN ATAU PERINGATAN}

Judulnya Ayat al-Quran yang penting dan kelihatannya sangat tepat untuk dikaji dalam melihat geneologi keberadaan wali nikah khususnya dalam budaya Islam awal adalah sebuah ayat Q.S al-Nur (24) 32:

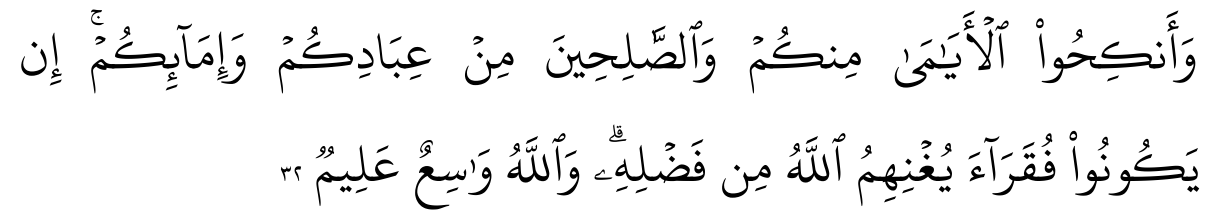

Artinya: dan kawinkanlah orang-orang yang sedirian diantara kamu, dan orang-orang yang layak (berkawin) dari hamba-hamba sahayamu yang lelaki dan hamba-hamba sahayamu yang perempuan.

Ayat diatas bisa diuraikan mengandung maksud sebagai berikut: pertama, dari teks redaksi al-Quran ayat 32 dari Q.S al-Nur jika dikaji berdasarkan pada kajian pembacaan bebas maka sebetulnya ayat tersebut berlaku universal baik laki-laki maupun perempuan. Ungkapan وانكحوا tidak mempunyai batas kekhususan perintah bagi laki-laki saja melainkan juga untuk wanita. Perintah mengawinkan itu tidak ada qarinah khusus bagi lakilaki yang pada gilirannya akan menjadikan seseorang laki-laki menjadi wali nikah. Perintah mengawinkan ini mempunyai kemungkinan diperintahkan juga bagi kaum perempuan yang nantinya bisa menjadi wali nikah juga.

Kedua, redaksi الايمى منكم والصلحين من عبادكم sebetulnya juga ditujukan untuk perempuan dan laki-laki. Tidak ada qarinah yang mewajibkan perempuan saja yang harus dinikahkan. Artinya bisa berarti kaum perempuan dan kaum laki-laki yang belum punya pasangan dinikahkan. Prioritas yang ada dalam ayat tersebut adalah الايمى Al-Quran telah memberikan keterangan adanya persamaan antara laki-laki dan perempuan dalam hal wali. Diberi walipun bagi mereka adalah khusus bagi mereka yang belum baligh atau belum bisa mengurus pribadinya. Meskipun tanpa wali, pernikahan sah tapi khusus mereka yang sudah bisa mengurus pribadinya.

${ }^{20}$ Yaitu orang yang masih sendiri, sehingga wajib diberi wali nikah tidak terbatas pada kaum wanita saja, melainkan juga untuk keduanya, yaitu kaum laki-laki dan perempuan yang belum bisa mengurusi urusan pribadi dan hartanya sebagaimana diperlakukannya seorang wali dalam Islam untuk mereka. 
Seseorang bisa memilih suaminya dan boleh pula melakukan akad nikah sendiri, baik ia perempuan perawan maupun janda. Tidak seorangpun mempunyai otoritas atas diri wanita yang sudah dewasa dan mampu mengurus urusan pribadi.

Mayoritas ulama terdahulu berpandangan bahwa (sesuai dengan konteks zamannya) perempuan dianggap sebagai orang yang kurang mampu dalam memlih pasangan yang tepat. Karena mereka akan mudah tertipu yang pada gilirannya hak-hak mereka akan terabaikan dan banyak mengalami kerugian. Untuk menghindari hal itu perlu ada wali yang dapat memilihkan pasangan yang sesuai atau setidaknya dapat dimintai persetujuan atau pertimbangannya. $^{21}$ Demikian, maka penempatan perempuan dewasa sebagai orang yang berada di bawah perwalian dalam akad nikah sesungguhnya merupakan pandangan ulama yang kontekstual.

Dengan kata lain, pandangan ulama terdahulu telah menempatkan perempuan sebagai orang yang tidak sempurna kecakapan bertindaknya sehingga perlu berada di bawah perwalian. Lalu apakah kemudian menempatkan perempuan di bawah perwalian tersebut untuk masa sekarang merupakan kemashlahatan bagi mereka ataukah sebaliknya justru yang timbul adalah kemahdlaratan. Pada prinsipnya kemampuan bertindak seseorang itu diukur dengan kemampuan akalnya, dan kemampuan akal seseorang diukur dengan kedewasaannya. ${ }^{22}$

Hubungannya wali dengan kemampuan bertindak ini sangat erat. Apabila perempuan diposisikan sebagai orang yang kurang sempurna kecakapan bertindaknya maka perempuan tidak dapat menikahkan dirinya sendiri, apalagi untuk menikahkan orang lain. Artinya perempuan tidak mungkin bisa menjadi wali, karena dalam pernikahannya sendiri dia harus menggunakan wali. Namun apabila dilihat bahwa kriteria orang yang memiliki kemampuan bertindak secara sempurna sebgaimana dikemukakan adalah manusia dewasa dan sehat akalnya, maka seseungguhnya perempuan dewasa juga dapat dipandang sebagai orang yang memilki kemampuan bertindak secara sempurna.

Kemudian apabila perempuan itu dianggap sempurna tindakannya maka ia tidak memerlukan wali dalam melakukan akad nikah, bahkan dia dapat menjadi wali bagi orang-orang yang memang patut berada di bawah

21 Dengan alasan yang sama, Abu Hanifah sendiri walaupun tidak mewajibkan, ia menganjurkan adanya wali (kerabat dekat) yang memberi pertimbangan kepada perempuan dewasa yang akan menikah. Lihat az-Zuhail, al-Fiqh al-Islami, Juz VII, h. 192, 195, dan 188189

22 Abd Wahab Khallaf, 'Ilm Usul al-Fiqh, (Ttp:Dar al-Tawzi' wa al-Nashr alIslamiyyah, 1993), h. 95-96 


\section{4 | Nurzulia Febri Hidayati}

perwaliannya seperti anak yang belum dewasa, orang gila dan orang yang kurang akalnya. ${ }^{23}$ Jadi, perempuan dewasa sebagaimana laki-laki dewasa dapat menjadi wali nikah. Hal ini tentu saja tergantung pada konteks masyarakatnya, sebagaimana kaidah yang menyatakan bahwa hukum dalam Islam dapat berubah dengan mempertimbangkan kemashlahatan sesuai dengan konteks ruang dan waktu. Dengan demikian apabila adanya wali nikah bagi perempuan dalam suatu masyarakat itu masih mashlahah maka perlu dipertahankan, dan begitu sebaliknya. Hanya saja fungsi wali tersebut pada dasarnya adalah sebagai pembimbing dan penasehat.

Melihat kontroversi fuqoha' tentang kedudukan wali nikah, dapat ditarik benang merah tentang hakikat dibutuhkannya wali bagi perempuan. Wali dibutuhkan karena perempuan dianggap tidak mampu mengetahui kemashlahatan nikah dan akibat-akibatnya. Ketidakmampuan perempuan ini menurut pemikiran Hanafiyyah ada pada diri perempuan yang belum dewasa, sehingga mereka menjadikan 'illat sighar (belum dewasa) sebagai alasan masih diperlukannya wali. Sementara fuqaha lain memandang ketidakmampuan perempuan itu berada pada diri perempuan yang masih perawan, meskipun sudah dewasa. Karenanya, mereka menjadikan bakarah sebagai 'illat perempuan butuh wali untuk menentukan masa depannya.

Oleh karena dalil-dalil yang dipakai masih muhtamil (mengandung banyak kemungkinan), maka Ibnu Rusyd menawarkan pemikiran middle road dengan memberi salah satu dari dua alternatif. Pertama, perwalian bukan syarat sah nikah, tetapi para wali mempunyai hak hisbah (semacam pengawasan). Kedua, jika wali dijadikan syarat nikah, maka tidak tepat bila ditentukan sifat, jenis dan tingkatannya. ${ }^{24}$ Keberadaan wali nikah yang semua jenis dan tingkatannya dari jenis laki-laki perlu ditinjau kembali. Jika 'illat perlunya wali bagi perempuan didasarkan atas ketidakmampuan dan kelemahan akalnya sehingga ia tidak mengetahui seluk-beluk dan akibat pernikahan, maka sifat-sifat tersebut tidak dapat diberlakukan kepada perempuan secara universal dan permanen.

Jadi, wali disini dipahami sebagai anggota keluarga baik dari pihak lakilaki maupun perempuan yang berkepentingan dengan pernikahan tersebut. Kedudukan wali disini pun tidak sebagai syarat dan atau rukun nikah, melainkan hanya sebagai kelompok yang selayaknya dimintai pertimbangan tentang terjadinya suatu pernikahan. Pemikiran semacam ini berdasarkan

23 Orang yang patut berada di bawah perwalian dalam hukum perdata disebut dengan handelings onbekwm. Mereka antara lain adalah orang yang berada di bawah umur atau belum dewasa (belum 21 tahun), gila, pemabuk dan pemboros. Kansil, Pengantar Ilmu Hukum dan Tata Hukum Indonesia, (Jakarta:PN Balai Pustaka, 1983), h. 117

24 Ibnu Rusyd, Bidayah al-Mujtahid wa Nihayah al-Maqashid, h. 7-9 
pemikiran tentang hakikat pernikahan, yang intinya adalah terjadinya kesepakatan dua pihak antara laki-laki dan perempuan untuk hidup bersama dengan melibatkan pihak lain untuk mengetahui terjadinya; bisa anggota keluarga dan bisa masyarakat lain.

Keterlibatan pihak lain dalam pernikahan tidaklah berkaitan dengan urusan intern kesepakatan dua pihak, melainkan sebatas sebagai pengawas atau kontrol sosial saja. Meskipun pernikahan merupakan urusan pribadi dua pihak, namun bagaimanapun juga sebuah keluarga yang tercipta melalui pernikahan itu merupakan bagian intergral dari masyarakat luas. Oleh karena itu, dalam konteks saat ini, ketika sudah terdapat pengakuan akan kedudukan perempuan yang sama dengan laki-laki di masyarakat, selain juga perempuan sudah tidak mendapatkan pembatasan untuk mendapatkan pendidikan maupun berperan di wilayah publik, masyarakat yang hendak dibangun dan diperbarui Islam adalah masyarkat bilateral; masyarakat yang menempatkan laki-laki dan perempuan pada posisi egaliter, bukan masyarakat yang mengutamkan patrelineal dan bukan pula masyarakat yang mengutamkan matrelineal. Maka adalah bertentangan dengan zaman prinsip egalitarianisme saat ini jika masih tetap menempatkan perempuan sebagai pihak yang tidak cakap hukum dalam melakukan akad pernikahan.

\section{PENUTUP}

Pada bagian ini menyajikan ringkasan dari uraian mengenai hasil dan pembahasan, mengacu pada tujuan penelitian. Berdasarkan kedua hal tersebut dikembangkan pokok-pokok pikiran baru yang merupakan esensi dari temuan penelitian.

Dari ulasan sebelumnya dapat disimpulkan bahwa madzhab dominan yang dianut umat Islam, terutama di Indonesia adalah bahwa pernikahan tidak sah apabila tidak ada atau tanpa persetujuan wali dari pihak perempuan. Pendapat ini didasarkan pada pemikiran bahwa perempuan dianggap tidak mampu atau tidak cakap menjaga keselamatan dirinya, baik karena ia belum dewasa maupun karena tidak memiliki pengalaman. Pendapat lain, meski tidak dominan dan banyak dianut di kawasan Muslim lainnya, bahwa wali tidak menjadi syarat sahnya pernikahan. Wali hanya menjadi sempurna tidaknya sebuah pernikahan. Pendapat terakhir ini diperkuat dengan tidak adanya nash yang eksplisit dari al-Quran mengenai perwalian dalam pernikahan. Perwalian dalam al-Quran hanya meliputi anak yatim dan dalam pengurusan harta mereka. Dengan demikian, wali nikah bagi perempuan bukan saja tidak perlu dan lebih dari itu, perempuan dapat menikahkan dirinya sendiri. 
66 | Nurzulia Febri Hidayati

\section{DAFTAR PUSTAKA}

Al-Hasby, Muhammad Bagir, Fiqh Praktis, Bandung: Mizan, 2002

Al-Husaini, Taqiyuddin Abu Bakar bin Muhammad, Kifayat al-Akhyar fi Hilli Ghayah al-Ikhtisar, Damaskus: Dar al-Khair, 1994, maktabah Syamilah

Al-Majmu', Imam Nawawi, Syarh al-Muhazddab, Juz 17

Al-San'ani, Muhammad Ibn Isma'il, Subul al-Salam Syarh Bulugh al-Maram min Adillat al-Ahkam, Juz II, Ttp: Dar al-Fikr, t.t

Al-San'ani, Muhammad Ibn Isma'il, Subul al-Salam Syarh Bulugh al-Maram min Adillat al-Ahkam, Juz II, Ttp: Dar al-Fikr, t.t

Al-Sharakhsi Syamsuddin, al-Mabsut, Juz V, Beirut: Dar al-Ma'rifah, 1989

Al-Zuhaili, Wahbah, Usul al-Fiqh al-Islami, Juz I, Damaskus:Dar al-Fikr, 1986 Abidin, Slamet dan Aminuddin, Fiqh Munakahat, Juz I, Bandung: Pustakan Setia, 1999

Kansil, Pengantar Ilmu Hukum dan Tata Hukum Indonesia, Jakarta:PN Balai Pustaka, 1983

Khallaf, Abd Wahab, 'Ilm Usul al-Fiqh, Ttp:Dar al-Tawzi' wa al-Nashr alIslamiyyah, 1993

Muchtar, Kamala, Asas-Asas Hukum Islam Tentang Perkawinan, Cet ke-3, Jakarta: Bulan Bintang, 1993

Nasution, Khoiruddin, Hukum Perkawinan I, Yogyakarta: Academia+Tazzafa, 2013

Nasution, Khoiruddin, Hukum Perkawinan I, Yogyakarta: AKAdeMIA + TAZZAFA, 2013

Perkawinan dan Kompilasi Hukum Islam, Bandung: Citra Umbara, 2017

Porwadarminta, KBBI, Jakarta: Balai Pustaka, 1995

Ramulyo, Moh. Idris, Tinjauan Beberapa Pasal Undang-Undang no 1 tahun 1974 dari Segi Hukum Perkawinan Islam, Jakarta: Ind-Hillco, 1985

Rusyd, Ibnu, Bidayat al-Mujtahid wa Nihayat al-Maqashid, Juz II, Ttp: Syirkat al-Nur Asia, t.t

Sabiq, Al-Sayyid Fiqh Sunnah, Juz II, Semarang: Maktabah wa Matba'at Toha Putera, t.t 